\title{
DESIGNING INFORMATION VISUALIZATION FOR HIGHER EDUCATION INSTITUTIONS: A PRE-DESIGN STUDY
}

\author{
Semiu Ayobami Akanmu \& Zulikha Jamaluddin \\ Universiti Utara Malaysia, Malaysia \\ ayobami.sm@gmail.com; zulie@uum.edu.my
}

\begin{abstract}
The multidimensionality of students' data and the limitations of the currently-used data management tools in higher education institutions (HEIs) have been identified as causes of constrained decision-making process in the domain. This, therefore, necessitates a pre-design study for the HEI students' datafocused InfoVis. The objectives of this study are to identify the prevailing practices of HEI data management, the data analytics methods that are generally employed by HEI data analysts and the comprehensive dimensions that are related to HEI students and adequate for conveying the domain explicit knowledge preferences. A mixed method approach with survey questionnaire and interview as data collection methods, is used. The contributions of this study, among others, are: (i) identification of the pattern and relationship of the domains explicit knowledge preferences; and (ii) the elicitation and description of students' data dimensions. These are expected to form the basis for the choice and implementation of the content delivery techniques in designing the domain-focused InfoVis. Our future works therefore entail developing the HEI InfoVis conceptual framework, designing the HEI students' data-focused InfoVis and conducting its users' experimental evaluation.
\end{abstract}

Keywords: Information visualization; pre-design study; data-driven decision making; multidimensional datasets; higher education institutions.

\section{INTRODUCTION}

The ever-growing nature and multidimensionality of students' data of Higher Education Institutions (HEIs) have resulted in constraints being experienced in decision-making processes of the domain. This experience has restricted HEIs' 
decision-makers and administrators in making good use of the students' data (Semiu \& Zulikha, 2014). In view of this, information visualization (InfoVis) - an arguably suitable tool for gaining insights into large multidimensional datasets - is suggested, because of its strength in aiding decision-making through visual exploratory ability (Ware, 2000; Spence, 2007).

Notably, InfoVis is a research domain on data analysis and knowledge discovery through visual exploration (Fekete \& Plaisant, 2002; Sheneiderman $\&$ Plaisant, 2010). It aids cognition and therefore supports decision-making. However, it is argued that InfoVis cannot be functional without a pre-design stage that thoroughly investigates the work practices of the domain actors and identifies the explicit knowledge expected to be delivered through it (Delavari \& Phon-Amnuaisuk, 2008; Lam, Bertini, Isenberg, Plaisant \& Carpendale, 2012; Koh, Slingsby, Dykes \& Kam, 2011). Understanding the work practices of the domain actors will inform the InfoVis' designers of the necessary information architecture and interface content that are needed in the design and implementation of the InfoVis. Also, identifying the explicit knowledge involved in the application areas of InfoVis can guide the transformation of the raw data (structured or unstructured) into meaningful information that can assist in decision-making and creation of knowledge and wisdom (Stasko, 2008). The transformed data can therefore produce explicit knowledge that fairly encapsulates what the InfoVis' users are eager to detect during the exploration of the massive datasets.

Considering the limitations in the currently-used data management tools in HEIs, it is necessary to have a specific InfoVis for the domain. Our on-going research is aimed at developing a HEI students' data-focused InfoVis. This paper discusses its pre-design study conducted mainly to investigate the work practices of the domain's actors - HEI decision- makers, data administrators and data analysts, and identify the explicit knowledge preferences of the domain's policy-makers.

\section{DECISION SUPPORT AS THE GENERAL THEME OF INFOVIS STUDIES}

On a general note, the need to transform large and multidimensional datasets to knowledge that can support decision-making through visualization, has resulted in continuous research on InfoVis. In this regard, creation of new visualization techniques, especially visual dynamic queries' mechanism, visual encoding methods, visual data mining techniques and conceptual design frameworks, have been the focus (Rogers et al., 2011; Sheinerderman \& Plaisant, 2010; Spence, 2007). 
Tan et al. (2006) pointed that InfoVis research needs to attend to challenges of data transformation and creation of new visualization techniques. To achieve this, an appropriate combination of visual data mining algorithms, dynamic queries' mechanisms and the visualization techniques must be accomplished. Numerous studies (Quigley, 2002; Robinson et al., 2005; Lee et al., 2005; Ziegler et al., 2008; Faisal el., 2008; Tory \& Staub-French, 2008; Oelke et al., 2008; Strobelt et al., 2009; Mansmann et al., 2009; Wanner et al., 2009; Hao et al., 2010; Keim et al., 2010; Johansson et al., 2010; Wu \& Ren, 2010; Roth et al., 2010; Kohlhammer et al., 2010; Yu et al., 2010; Stoffel et al., 2010; Zheng et al., 2011; Koh et al., 2011; Schaefer et al., 2011; Lirong et al., 2011; Simon et al. 2011; Meyer, 2012; Wang et al., 2012; Krstajic, 2012; Stoffel et al., 2012; Zhong et al., 2012; Ning et al., 2012; Pinto et al., 2012 Bowen, 2013) in different domains have been undertaken, concerning design of InfoVis frameworks, but none addresses the data on HEIs students' explicit knowledge. Table 1 summarizes these previous studies into domains and references with their respective contributions.

Table 1

Summary of Previous Studies on Domain, References, Niche and the Contributions

\begin{tabular}{|c|c|c|}
\hline Domain & References & Contribution \\
\hline \multirow[t]{2}{*}{ Genomes } & Meyer (2012) & $\begin{array}{l}\text { A visualization techniques to aid the exploration } \\
\text { of genetic data by biologists }\end{array}$ \\
\hline & Simon et al. (2011) & $\begin{array}{l}\text { A visualization that detects overlapping genes in } \\
\text { bacterial genomes }\end{array}$ \\
\hline \multirow[t]{3}{*}{$\begin{array}{l}\text { Information } \\
\text { Retrieval }\end{array}$} & Wang et al. (2012) & $\begin{array}{l}\text { A visualization that enhances information retrieval } \\
\text { process in PLM }\end{array}$ \\
\hline & Lirong et al. (2011) & $\begin{array}{l}\text { A novel visualization technique for web retrieved } \\
\text { credit information }\end{array}$ \\
\hline & Tekir et al. (2011) & A visualization for web document clustering \\
\hline \multirow{5}{*}{$\begin{array}{l}\text { Public and business } \\
\text { administration } \\
\text { through opinion } \\
\text { mining }\end{array}$} & $\begin{array}{l}\text { Kohlhammer et al. } \\
\text { (2010) }\end{array}$ & $\begin{array}{l}\text { A visual analytics that helps in policy and } \\
\text { administrative decision-making }\end{array}$ \\
\hline & Wanner et al. (2009) & $\begin{array}{l}\text { Visual sentiment analysis of the RSS News feeds } \\
\text { for monitoring the US Presidential election of } \\
2008\end{array}$ \\
\hline & Oelke et al. (2008) & $\begin{array}{l}\text { An InfoVis' technique that visually represents } \\
\text { customers' feedback data }\end{array}$ \\
\hline & Hao et al. (2010) & $\begin{array}{l}\text { A geo-temporal visualization on customers' } \\
\text { feedback stream, and for product marketing }\end{array}$ \\
\hline & Krstajic (2012) & $\begin{array}{l}\text { An InfoVis work on visual text analytics of news } \\
\text { story development for policy assessment }\end{array}$ \\
\hline
\end{tabular}

(continued) 


\begin{tabular}{lll}
\hline Domain & References & Contribution \\
\hline Software & Harrison et al. & InfoVis software for visualizing chemical \\
engineering & $(2010)$ & structure. \\
& Stoffel et al. (2012) & $\begin{array}{l}\text { A web-based visual query analysis system for the } \\
\text { simulation of micro-grid energy mix }\end{array}$
\end{tabular}

Financial and investment analysis

Schaefer et al. (2011)

Lee et al. (2005)

Community

Bowen (2013)

Public health

Geography and Climatology

Robinson et al. (2005) (2010) informatics

Ziegler et al. (2008)

A pixel-based visual analytics that supports investors in making financial market-related decisions.

A novel explorative tool for the analysis and visualization of financial time-series data.

An InfoVis tool that shows trend and activity of a conference community.

Visualization that uses network technique to show the co-authorship connection among the academic community.

Sopan et al. (2012)

A geo-visualization tool that explores geographic health data

A geospatial and multivariate data visualization tool for public health datasets

Koh et al. (2011) An InfoVis tool as a support system for the wide range of decision-making processes.

Ning et al. (2012) An InfoVis application used to support doctors' diagnosis through intuitive ways of learning about the patients' condition.

Yu et al. (2012) An exploratory visual approach to aid the analysis of temporal patterns of eye movement.

Johansson et al. An InfoVis tool that evaluates climatic conditions

Wu and Ren (2010)

An InfoVis mechanism with augmented reality for the representation of spatial data.

Roth et al. (2010) InfoVis tool for crime analysis and control.

Zhong et al. (2012); An interactive dymaxion map and web-based Tory and StaubFrench (2008) InfoVis interface which are tools for conveying research output to practitioners in the building industries.

Library and Stoffel et al. (2010) information science

Oelke et al. (2008); Visualization of document summarization and Strobelt et al. (2009) analysis 


\begin{tabular}{lll}
\hline Domain & References & Contribution \\
\hline Higher Education & Pinto et al. (2012), & (i) U-Map 2, an InfoVis tool used for classification \\
Institution & of European HEIs. It aids in updating information \\
& for institutional participation; (ii) University \\
& Autonomy in Europe3, an InfoVis tool for the \\
& ranking of countries based on financial, staffing, \\
& organizational and academic autonomy; (iii) \\
& U-Multirank4, an InfoVis tool used as ranking tool \\
& for institutions; and (iv) MAUNIMO5, an InfoVis \\
& tool used for drawing attention to the varieties of \\
& academic mobility. \\
\hline
\end{tabular}

However, based on the review of the available previous works on InfoVis design, as presented in Table 1, there is yet an InfoVis tool that can be specifically used to explore the students' data, in view of conveying the preferred knowledge of the domain actors through an interactive and communicative interface. Due to its fast growing pace, HEIs' data is becoming increasingly difficult to analyse so as to detect previously unknown information that could assist policy and decision-making in the education sector (Oracle Data Sheet, 2011; Yanosky, 2009). The currently used data management systems by the HEIs are the traditional management information systems and data mining technologies which are saddled with problems of money and time wastage, loss of scientific and industrial opportunities and inability to exploit its hidden information (Sarker et al., 2010; Pocius \& Reklaitis, 2000; Bresfelean et al., 2009). Other recorded cases are the use of static statistical graphics like pie chart, bar chart and line chart (Ehlers et al., 2009), occasional deployment of popular statistical tools like SAS and software systems, like Tableau for the HEIs' operational data analysis (Conrad et al., 2013). However, the multidimensionality of these datasets has limited the success of these traditional data management systems and data representation using the static graphics.

As shown in the diverse areas where InfoVis' adoptions have been made, InfoVis' value lies in its ability to solve problems of information overload, hence, assisting in decision-making through its information filtering and visualization features. It has also been shown that each of the domains reviewed has the design of its InfoVis framework in alignment with the practices of the domain and its peculiar decision-making support - through the systematic combination of the visualization, interaction and visual data mining techniques (Keim et al., 2008). Having understood the diverse applicability and indispensable usage of InfoVis, this study is thus motivated by the lingering problem of information overload in managing the data of HEI students and the consequent constraints in related decision-making (Semiu \& Zulikha, 2014). 


\section{LITERATURE REVIEW}

Most previous InfoVis pre-design studies (Robinson et al., 2005; Isenberg et al., 2008; Hinrichs et al., 2008; Mansmann et al., 2009; Roth et al., 2010; Grammel et al., 2010; Huang et al., 2010; Jung et al., 2011; Koh et al., 2011; Zhong et al., 2012) have extensively employed qualitative method for users' studies; while Tory et al. (2008) used mixed methods. All these studies designed their research process to cater to the objectives of their studies and answer their research questions.

As argued by Creswell (2009), mixed method has the ability to provide a deeper insight to answering research questions. Our study also employs mixed method so as to adequately accomplish our research objectives, which are:

i. To identify the prevailing practices of HEIs' data management;

ii. To identify the data analytics methods that are generally employed by HEIs' data analysts; and

iii. To identify the comprehensive dimensions related to HEI students which are adequate for conveying the domain explicit knowledge preferences.

\section{METHODOLOGY}

Due to the nature of the work of HEI data analysts and administrators, understanding their administrative activities to identify the prevailing practices of HEI data management and data analytics methods is better done through a qualitative method. Therefore, interview, as supported by Rogers et al. (2011) and Sheinerderman and Plaisant (2010), is employed.

The interview sessions for the data administrators and data analysts are of approximately thirteen (13) and eleven (11) minutes, respectively. The interview sessions were recorded using an audio tape recorder, and subsequently transcribed. The transcription is manually coded to inter-relate themes and their descriptions. These themes practically address the questions asked during the interview sessions. Table 2 presents the code tags, terms, quoted comments and themes.

The code tags are the identities given to the interviews conducted. The term is the participant's category while the theme is the unifying idea from the quoted comments which are excerpts from the transcribed texts. 
Table 2

Code Tags, Terms, Quoted Comments and Themes

\begin{tabular}{lll}
\hline Code tags Term & Quoted Comments & Themes \\
\hline 1. & Data Management & "But at the moment, what we do right Adhoc data \\
& now is to check the data needed and extraction practice \\
& extract the data, put in one place and \\
& use what we use now.."
\end{tabular}

"There are two databases for the Decentralised data students. One is for the undergraduate, storage and the second one is for the post graduate. Staffs have another database."

2. Data Analytics "We extract from system, from data Traditional
warehouse, then we analyse, do descriptive
statistics in Microsoft Excel"

"Yes, PowerPivot. Ok. My team, Utilization of data we extract the useful data from our administrative operational database, and then provide technologies same to UPK."

"And for the reporting, it is quite easy. We have to use SQL Server Reporting System.... Microsoft Excel, PowerPivot"

"If they need the total of students, we just figure out. We don't use any analysis that is complicated, or with complicated tools. We just use Microsoft Office; Excel and Access. The data warehouse converts to Access, and we analyse using Excel. Just Microsoft, Microsoft products"

On the other hand, to identify the comprehensive dimensions related to HEI students and adequate for conveying the domain explicit knowledge preferences, a survey questionnaire is designed and administered to a total number of thirty (32) respondents chosen among HEI decision-makers, as a purposive sample. The respondents are Assistant Registrars, Registrars, Deans, Deputy Deans, Program Coordinators and Heads of Departments. The survey questionnaire (Items are presented in Table 3) contains twenty-nine (29) HEI decision-makers' explicit knowledge preferences which had earlier been elicited from literature review (Semiu \& Zulikha, 2016). 


\section{Table 3}

\section{Identifying the HEI-Focused Explicit Knowledge from the Students' Data}

\section{S/N Items:}

At my institution, we seek to know...

1. The pattern of various groups of students based on their race, religion, sex and nationality.

2. The pattern of previous graduates based on their race, religion, sex and nationality.

3. The pattern (course of study, CGPA and nationality) of the Alumni who are responsive to the university's invitation.

4. The relationship between the students' performance and their gender, race and nationality.

5. The trend of the students' enrolment based on their nationality and sex.

6. The trend of the students' enrolment based on their mode of admission and gender.

7. The relationship between students' mode of entry (foundation, matriculation, credit transfer), criteria set for admission, and their academic performance.

8. The pattern of the students' economic status (self/family sponsored and scholarship) per enrolment.

9. The performance of students with disabilities.

10. The performance of students with unfavourable health history.

11. The trend and pattern of the university's graduating students based on gender, race and nationality.

12. The relationship between the graduating students' performance with their gender, race and nationality.

13. The relationship between students' course of study and their employability.

14. The relationship between students' course majors and their employability.

15. The relationship between students' performance and their lecture venue and time.

16. The relationship between students' course majors and their performance.

17. The trend of the students' performance in relationship with number of semesters used.

18. The relationship between the students' performance and their programme of study (degree \& graduate).

19. The relationship between the students' performance and their mode of study (full time \& part time).

20. The pattern of students in a particular department, school or college based on race, gender and nationality.

21. The courses that are majorly or otherwise enrolled by the students.

22. The relationship between the majorly (or otherwise) enrolled course and the students' performance in the said course.

23. The relationship between the students' performance and their English language proficiency.

24. The pattern of the drop-out students.

25. The relationship between drop-out students and their economic status (self/family sponsored and scholarship) and health history.

26. The pattern of the drop-out students based on their gender, nationality and marital status.

27. If there is impact of soft skills acquisition on the students' academic performance.

28. The significance of internship on the students' employability.

29. About the students' deferment history and its relationship with students' performance. 
Frequency distributions are calculated for each of the explicit knowledge items to weigh their preferences using a dichotomous response (Yes and No) (Neuman, 2007; Pallant, 2010). Items with more than eight (8) "No" responses are invalidated, using the Quartile approach to Item weighting. Note: 8 is approximately the lower quartile (Q1) of 32 (Total number of the respondents). It is derived from this formula: $1 / 4(n+1)$, where $n=32$. From the analysis, items 3 and 15 are invalidated.

\section{FINDINGS}

\section{Identifying the prevailing practices of HEIs'data management}

The data administrator's department of the institution handles the extraction of any requested data. The request and usage of the data is mostly done by the university's corporate planning unit. From the information provided, it is evident that the presently used data management tools, like Microsoft SQL Server for data warehousing, can be easily linked to visual exploratory system, using a suitable Application Programming Interface (API).

\section{Identifying the currently-used data analytics methods in HEI}

We find that Microsoft Excel and Excel Power Pivot are the most used data analysis tools. The usual descriptive statistics is done by Microsoft Excel while bar chart, pie chart and line chart are preferred statistical graphics to data analysts due to their data communicative abilities. Both the data administrator and analyst positively review the presently used tools but wish to explore better ones that could ease their work practices and enhance their experiences.

\section{Identifying the comprehensive and adequate dimensions related to HEI} students for conveying the domain's explicit knowledge preferences

The validated items of the HEI policy-makers' explicit knowledge are summarized as follows:

i. The patterns of: various groups of students based on their race, religion, sex and nationality; colleges; previous graduates based on their race, religion, sex and nationality; course of study, and Cumulative Grade Point Average (CGPA);

ii. The relationship between the students' performance and their gender, race and nationality; mode of entry; disabilities; health history; course major; number of semesters used; program of study; mode of study; intensively enrolled courses; English language proficiency; soft skills acquisition; and deferment history; 
iii. The relationship between drop-out students and their economic status; gender, nationality and marital status;

iv. The relationship between students' employability and internship record; course major; course of study; and

v. The students' enrolment pattern based on nationality, gender; sex; mode of admission.

Based on the validated explicit knowledge preferences, we elicit the comprehensive data dimensions that must be modelled into the InfoVis domain for adequate conveyance of the intended knowledge. This can also guide the choice and implementation of the visualization, interaction and analytics techniques. Table 4 presents the data dimensions of HEI students and their description:

Table 4

HEI Students' Data Dimensions and their Descriptions

\begin{tabular}{|c|c|c|c|c|}
\hline & $\begin{array}{c}\text { Data } \\
\text { Dimensions }\end{array}$ & Class & Data Type & Descriptions \\
\hline 1 & Gender & Basic & Categorical & $\begin{array}{l}\text { This represents the students' gender, i.e., Male } \\
\text { or Female. }\end{array}$ \\
\hline 2 & Nationality & & Categorical & $\begin{array}{l}\text { The citizenship identity of the students. } \\
\text { E.g., Malaysia, India, Nigeria, etc. }\end{array}$ \\
\hline 3 & Race & & Categorical & $\begin{array}{l}\text { Continent-based identity. } \\
\text { E.g., African, Asian, American, etc. }\end{array}$ \\
\hline 4 & Religion & & Categorical & $\begin{array}{l}\text { The faith identity of the student. E.g., Islam, } \\
\text { Buddhism, Christianity, etc. }\end{array}$ \\
\hline 5 & $\begin{array}{l}\text { Course of } \\
\text { Study }\end{array}$ & & Categorical & $\begin{array}{l}\text { The course that the student is taking. } \\
\text { E.g., Information Technology (IT), Business } \\
\text { Administration, etc. }\end{array}$ \\
\hline 6 & Specialization & & Categorical & $\begin{array}{l}\text { When applicable, this describes the area in } \\
\text { which the student is specializing. } \\
\text { E.g., Artificial Intelligence as a specialization } \\
\text { for IT students. }\end{array}$ \\
\hline 7 & Year of Entry & & Numeric & $\begin{array}{l}\text { The year that the student entered the university. } \\
\text { E.g., } 2010 \text {, etc. }\end{array}$ \\
\hline 8 & $\begin{array}{l}\text { Year of } \\
\text { graduation }\end{array}$ & & Numeric & $\begin{array}{l}\text { The year that the student graduated (or will } \\
\text { graduate) from the university. } \\
\text { E.g., 2010, etc. }\end{array}$ \\
\hline 9 & $\begin{array}{l}\text { Number of } \\
\text { Semester Used }\end{array}$ & & Numeric & $\begin{array}{l}\text { The number of semesters used by the student. } \\
\text { E.g., } 2,3,4 \text {, etc. }\end{array}$ \\
\hline
\end{tabular}

(continued) 


\begin{tabular}{|c|c|c|c|c|}
\hline & $\begin{array}{c}\text { Data } \\
\text { Dimensions }\end{array}$ & Class & Data Type & Descriptions \\
\hline 10 & $\begin{array}{l}\text { Mode of } \\
\text { Admission }\end{array}$ & & Categorical & $\begin{array}{l}\text { This describes the entry method into the } \\
\text { university. } \\
\text { E.g., SPM, Matriculation, Diploma. }\end{array}$ \\
\hline 11 & $\begin{array}{l}\text { Mode of } \\
\text { sponsorship }\end{array}$ & & Categorical & $\begin{array}{l}\text { This describes how the student is sponsoring } \\
\text { his or her education. E.g., Loan, Family, Self- } \\
\text { Study and Scholarship. }\end{array}$ \\
\hline 12 & Current CGPA & & Real Number & $\begin{array}{l}\text { The current grade of the student which is } \\
\text { normally with fractions. E.g., } 3.2,3.7 \text {, etc. }\end{array}$ \\
\hline 13 & $\begin{array}{l}\text { Studentship } \\
\text { Status }\end{array}$ & & Categorical & $\begin{array}{l}\text { This is to show the status of the student. } \\
\text { E.g., Active, Non-Active, Drop-Out. }\end{array}$ \\
\hline 14 & $\begin{array}{l}\text { English } \\
\text { Language } \\
\text { Proficiency }\end{array}$ & & Categorical & $\begin{array}{l}\text { When applicable, this gives the English } \\
\text { language certification record of the student. } \\
\text { E.g., MUET, IELTS, TOEFL, etc. }\end{array}$ \\
\hline 15 & Disability & & Categorical & $\begin{array}{l}\text { When applicable, the disability type of the } \\
\text { student is stated. } \\
\text { E.g., Physical, Hearing Impairment, etc. }\end{array}$ \\
\hline 16 & Mode of Study & & Categorical & $\begin{array}{l}\text { This is to categorize students on full-time and } \\
\text { part-time basis. }\end{array}$ \\
\hline 17 & $\begin{array}{l}\text { Program of } \\
\text { Study }\end{array}$ & & Categorical & $\begin{array}{l}\text { The program the student is undertaking. The } \\
\text { values here are: BSc, PGD, MSc, PhD and } \\
\text { DBA. }\end{array}$ \\
\hline 18 & $\begin{array}{l}\text { Internship } \\
\text { length }\end{array}$ & Derived & Numeric & $\begin{array}{l}\text { The total number of months the students used } \\
\text { on internship. }\end{array}$ \\
\hline 19 & $\begin{array}{l}\text { Soft skill } \\
\text { quality }\end{array}$ & & Numeric & $\begin{array}{l}\text { The total number of workshops or seminars on } \\
\text { soft skills (public speaking, leadership, time } \\
\text { management, etc.) acquisition attended. }\end{array}$ \\
\hline 20 & $\begin{array}{l}\text { Health } \\
\text { soundness }\end{array}$ & & Numeric & $\begin{array}{l}\text { This is calculated by the addition of number } \\
\text { of times the students visited the hospital and } \\
\text { the number of times he/she was medicated, } \\
\text { divided by the total number of semesters used. }\end{array}$ \\
\hline 21 & Employability & & Numeric & $\begin{array}{l}\text { The total number of months that graduated } \\
\text { students used before being gainfully employed. }\end{array}$ \\
\hline 22 & $\begin{array}{l}\text { Deferment } \\
\text { length }\end{array}$ & & Numeric & $\begin{array}{l}\text { The total number of semesters that the student } \\
\text { deferred his or her registration. }\end{array}$ \\
\hline
\end{tabular}

As shown in Table 4, the derived data attributes are computed (derived) through addition and division operations, as applicable. These derived data variables are products of diligent extraction from their respective information repositories. For example, health soundness which is computed through the addition of number of times a student visited the hospital and the number of times he/she was medicated, divided by the total number of semesters used 
- and other derived data variables - are new. They are basically chosen as operational computations to realize atomic data variables that can fit into the students' data analytics and that appeal to the domain's pre-design findings. On the other hand, the basic data variables are fundamentally known units; so, they are with no computational operations.

\section{DISCUSSION AND CONCLUSION}

The findings from the interview sessions highlight the necessity for a better tool that can attend to the limitations of the present ones. We opine that a tool, like InfoVis, which shares visualization and presentation similarity with the currently used traditional bar chart, pie chart and line chart of Microsoft Excel, is a good choice. Also, InfoVis' analytical strength can be leveraged with interaction techniques and visual query mechanism. This will make the tool usable to everyone irrespective of their knowledge of statistics.

With the identified and validated explicit knowledge preferences, this study has reliably elicited a comprehensive data dimension expected of each data instance in the HEI students' datasets. Notably, due to the decentralised data storage practice, many of the data dimensions (e.g., Soft skills quality, Internship length, Employability, etc.) are not presently covered by the students' academic record. We therefore posit that for a functional HEI student-focused InfoVis, the elicited data dimensions are the expected data fields of the database table.

The identification of HEI current data management practices and the elicitation of domain policy-makers' explicit knowledge preferences are essential findings from this study. Also, the data dimensions guide the choice of visualization, interaction and analytic techniques which are InfoVis' content delivery techniques and components of its conceptual framework.

Our future works thereby entail developing the HEI InfoVis conceptual framework, designing the HEI students' data-focused InfoVis and conducting its users' experimental evaluation.

\section{REFERENCES}

Bowen, J. P. (2013). Online communities: Visualization and formalization. Proceedings of the Second International Workshop on Cyberpatterns: Unifying Design Patterns with Security, Attack and Forensic Patterns. Abingdon, UK, 8-9 July. 
Bresfelean, V. P., Ghisoiu, N., Lacaurezeanu, R., \& Sitar-Taut, D. A. (2009). Towards the development of decision support in academic environments. Proceedings of International Conference on Information Technology Interfaces, ITI, '09, pp. 343-348.

Conrad, C., Gasman, M., Lundberg, T., Nguyen, T-H., Commodore, F., Samayoa, A. C. (2013). Using educational data to increase learning, retention, and degree attainment at Minority Serving Institutions (MSIs), A Research Report of Penn Graduate School of Education, GSE.

Creswell, J. (2009). Research Design: Qualitative, quantitative and mixed approaches (3rd ed.). United States of America: Sage.

Delavari, N., Phon-Amnuaisuk, S., \& Beikzadeh. M. R. (2008). Data mining application in higher learning institutions. Institute of Mathematics and Informatics, Vilnus, 7(1), 31-54.

Ehlers. K., Joubert, M., Kinghorn, J., \& van Zyl, A. (2009). Decision support system for institutional research management in higher education: Data mining to determine research focus, intensity and synergy. Proceedings of International Conference on Computational Science and Engineering

Faisal, S., Craft, B., Cairns, P. \& Blandford, A. (2008). Internalization, qualitative methods, and evaluation. Proceedings of the 2008 Conference on Beyond Time and Errors: Novel Evaluation Methods for Information Visualization, pp. 1-8. Association for Computing Machinery.

Fekete, J-D. \& Plaisant, C. (2002). Interactive information visualization of a million items. Proceedings of the IEEE Symposium on Information Visualization (InfoVis '02).

Grammel, L., Tory, M. \& Storey, M-A. (2010). How Information Visualization Novices Construct Visualizations. IEEE Transaction on Visualization and Computer Graphics, 16(6), 943-952.

Hao, M. C., Dayal, U., Sharma., Keim, D., \& Janetzko, H. (2010). Visual analytics of large multi-dimensional data using variable binned scatter plots, in visualization and data analysis. Proceedings of IS \& T/SPIE Electronic Imaging, Science and Technology, Belligham.

Hinrichs, U., Schmidt, H., \& Carpendale, S. (2008). EMDialog: Bringing information visualization into the museum. IEEE Transaction on Visualization and Computer Graphics, 14(6), 1181- 1188. 
Huang, J. Y., Li, Y., Zhang, J. M., \& Yu, J. (2010). Developing novel design patterns in information visualizations for mobile health systems. Proceedings of 2010 3rd International Conference on Biomedical Engineering and Informatics (BMEI 2010), pp. 2748-2752.

Isenberg, P., Tang, A., \& Carpendale, S. (2008). An exploratory study of visual information analysis, CHI Proceedings: Visualization to Support Information Work, April 5-10, 2008, pp. 1217-1226.

Johansson, J., Nest, T. S. \& Linner, B. (2010). Evaluating climate visualization: An information visualization approach. Proceedings of IEEE 2010 14th International Conference on Information Visualization, pp. 156- 161.

Jung, H., Lee, M., Kim, P., \& Kim, D. (2011) Study on the Visualization Elements of Web Information Services - Focused on Researcher Network and Graphics Chart, Proceedings of 2011 Eighth International Conference on Information Technology: New Generations, pp. 459-463.

Keim, D., Andrienko, G., Fekete, J-D., Gorg, C., Kohlhammer, J. \& Melancon, G. (2008). Visual Analytics: Definition, Process, and Challenges. A Kerren et al. (Eds): Information Visualization, LNCS 4950, pp. 154175. Springer-Verlag Berlin Heidelberg.

Keim, D., Pras, A., Schonwalder, J., Wong, P. C. \& Mansmann, F. (2010). Report on the Datgstuhl Seminar on Visualization and Monitoring of Network Traffic. Journal of Network and Systems Management, 18(2), 232-236.

Koh, L.C., Slingsby, A., Dykes, J., \& Kam, T. S. (2011). Developing and applying a user-centred model for the design and implementation of information visualization tools. Proceedings of 15th IEEE International Conference on Information Visualization, IEEE Computer Society.

Kohlhammer, J., Ruppert, T., Darvey, J., Mansmann, F. \& Keim, D. (2010). Information visualization and visual analytics for governance and policy modelling. CROSSROAD Call for Contribution on Future Internet on ICT for Governance and Policy Modelling, 2010.

Krstajic, M., Najm-Araghi, M. Mansmann, F. \& Keim, D. (2012). Incremental visual text analytics of news story development. Proceedings of Conference on Visualization and Data Analysis (VDA '12). 
Lam, H., Bertini, E., Isenberg, P., Plaisant, C. \& Carpendale, S. (2012). empirical studies in information visualization: Seven scenario, IEEE Transaction on Visualization and Computer Graphics, 18(9), $1520-1536$

Lee, B., Czerwinski, M., Roberston, G. \& Bederston, B. B. (2005). Understanding research trend using paperlens. Proceedings CHI 2005, Portland, Oregon, USA.

Lirong, X., Mengium, W. \& Jing, F. (2011). A visualization system for web retrieved credit information. Proceedings of Seventh International Conference on Natural Computation, pp. 728-732.

Mansmann, F., Fisher, F., Keim, D. A. \& North, S. C. (2009). Visual support for analyzing network traffic and intrusion detection events using treemap and graph representations. Proceedings of the 3rd ACM Symposium on Computer Human Interaction for the Management of Information Technology (CHiMiT '09), pp. 19-28.

Meyer, M. (2012). Designing visualization for biological data. A Keynote talk at 3rd Leonardo Satellite Symposium of Arts, Humanities and Complex Networks (NetSci, 2012).

Neuman, L.W. (2007). Basics of social research: Qualitative and quantitative approaches, (2nd ed.) Pearson International, USA.

Ning, Z., Wenxing, H., Siting, Z. \& Li, T. (2012). A solution for an application of information visualization in telemedicine. Proceedings of the 7th International Conference on Computer Science \& Education (ICCSE, 2012), Melbourne, Australia, pp. 407-411.

Oelke, D., Bak, P., Keim, D. A., Last, M. \& Danon, G. (2008). Visual evaluation of text features for documents summarization and analysis. Proceedings of IEEE Symposium on Visual Analytics Science and Technology, Columbus, Ohio, USA.

Oracle Data Sheet (2011). Oracle Higher Education Constituent Hub (HECH). Retrieved from http://www.oracle.com/us/products/applications/masterdata-management/education-research-hech-ds-164687.pdf

Pallant, J. (2010). SPSS survival manual: A step by step guide to data analysis using SPSS for Windows (Version 16). Australia: Allen \& Unwin. 
Pinto, M., Raposo, R. \& Ramos, F. (2012). Comparison of emerging information visualization tools for higher education. Proceedings of 16th International Conference on Information Visualization, pp. 100-105.

Pocius, K. \& Reklaitis, V. (2000). Web-based services for technology education management and planning. Proceedings of International Workshop on Advanced Learning Technologies, IWALT, 2000, pp. 284- 285.

Quigley, A. J. (2002). Experience with FADE for the visualization and abstraction of software views.Proceedings in 10th International Workshop on Programme Comprehension, IWPC '02.

Robinson, A. C., Chen, J., Lengerich, E. J., Meyer, H. G. \& MacEachren, A. M. (2005). Combining usability techniques to design geovisualization tools for epidemiology. Cartography and Geographic Information Science, 32 (4), 243-255.

Rogers, Y., Sharp, H. \& Preece, J. (2011). Interaction design: Beyond human computer interaction (3rd ed.). United Kingdom. John Wiley \& Sons, Limited.

Roth, R. E., Ross, K. S., Finch, B. G., Luo, W., \& MacEachren, A. M. (2010). A user-centered approach for designing and developing spatiotemporal crime analysis tools. In Sixth International conference on Geographic Information Science.

Sarker, Farhana, Davis, Hugh, Tiropanis, \& Thanasis (2010). The role of institutional repositories in addressing higher education challenges. The Second International Workshop on Semantic Web Application in Higher Education, University of Southampton, UK.

Schaefer, M., Wanner, F., Kahl, R., Zhang, L., Schreck, T. \& Keim, D. A. (2011). A novel explorative visualization tool for financial time series data analysis. Proceedings of VAW, University College London, UK.

Semiu, A. \& Zulikha J. (2014). Towards developing an instrument in measuring the need for InfoVis. Proceeding of Knowledge Management International Conference, Langkawi, pp. 628-631, Malaysia- KMICe 2014, Aug., 12-15, 2014.

Semiu, A., \& Zulikha J. (2016). Students' data-driven decision making in HEI: The explicit knowledge involved. International Journal of Information and Education Technology, 6(1), 71-75. 
Sheneiderman, B. \& Plaisant, C. (2010). Designing the user interface: Strategies for effective human-computer interaction (5th ed). U.S.A: Pearson Higher Education.

Simon, S., Oelke, D., Landstorfer, R., Neuhaus, K. \& Keim, D. (2011). Visual analysis of next-generation sequencing data to detect overlapping genes in bacterial genomes. Proceedings of IEEE Symposium on Biological Data Visualization, October 23-24, Providence Island, USA, page 47- 54.

Sopan, A., Song-le Noh, A., Karol, S., Rosenfeld, P., Lee, G., A Shneiderman, B. (2012). Community health map: A geospatial and multivariate data visualization tool for public health datasets. Government Information Quarterly, 29, 223-234.

Spence, R. (2007). Information vsualization: Design for interaction (2nd ed.). England: Pearson Education Limited.

Stasko, J. (2008). Visualization for information exploration and analysis. Proceedings of IEEE Symposium on Visual Languages and HumanCentric Computing (VL/HCC '08).

Stoffel, A., Spretke, D., Kinnemann, H. \& Keim, D. A. (2010). Enhancing document structure analysis using visual analytics. Proceedings of the 2010 ACM Symposium on Applied Computing (SAC'10), pp. 8-12, 2010.

Stoffel, A., Zhang, L., Weber, S. H. \& Keim, D. A. (2012). AMPLIO VQAA web-based visual query analysis system for micro grid energy mix planning. Proceedings of International Workshop on Visual Analytics, the Eurographics Association, 2012.

Strobelt, H., Oelke, D., Rohrdantz, C. \& Stoffel, A. (2009). Document cards: A top trumps visualization for documents. IEEE Transaction on Visualization and Computational Graph. 15(6):1145-52. doi: 10.1109/ TVCG.2009.139.

Tan, P-N, Steinbach, M; \& Kumar, V. (2006). Introduction to data mining (1st ed.). U.S.A. Pearson Education.

Tekir, S., Mansmann, F; \& Keim, D. (2011). Geodesic Distances for web document clustering. Proceedings of IEEE Symposium on Computational Intelligence and Data Mining (CIDM, 2011). 
Tory, M. \& Staub-French, S. (2008). Qualitative analysis of visualization: A building design field study. ACM Proceedings of BELIV, 2008, Florence, Italy, pp. 1-8.

Wang, H., Zhao, G., Wang, W. \& Chen, C. (2012). The design and implementation of the platform of interactive information visualization on aircraft product development. Proceedings of 3rd International Conference on System Science, Engineering Design and Manufacturing Informatization, pp. 180-184.

Wanner, F., Rohrdantz, C., Mansmann, F., Stoffel, A., Oelke, D., Kristajic, M., Keim, D. A, Lou, D., Yang, J., \& Atkinson, M. (2009). Large-scale comparative sentiment analysis of news articles. Proceedings of InfoVis Conference '09.

Ware, C. (2000). Information Visualization: Perception for design. United States of America: Morgan Kaufmann Publishers.

Wu, X. \& Ren, F. (2010). Mechanism and methods of outdoor AR spatial information visualization representation. Proceedings 2010 Second International Conference on Computer Modelling and Simulation, pp. 272- 276, IEEE Computer Society.

Yanosky, R. (2009). Institutional data management in higher education. A Report from EduCause Centre for Applied Research. Retrieved from http://net.educause.edu/ir/library/pdf/EKF/EKF0908.pdf

Yu, C., Yurovsky, D. \& Xu, T. (2012). Visual data mining: An exploratory approach to analyzing temporal patterns of eye movement. Infancy, 17(1), 33-60.

Zheng, X-Z., Wang, S-L., Luo, J-H., Cao, Y., \& Qing, D-Z. (2011). Research on the framework of information visualization system of equipment support decision-making. Proceedings of 2011 International Conference on Computational and Information Science, pg. 780- 784 IEEE Computer Society.

Zhong, C., Wang, T., Cairns, S., \& Arisona, S. M. (2012). Using an interactive dymaxion map to convey research information through visualization. Proceedings of 16th International Conference on Information Visualization, IEEE Computer Society. 
Ziegler, H., Nietzschmann, T., \& Keim, D. (2008). Visual analytics on the financial market: Pixel-based analysis and comparison of long-term investments. Proceedings of the 12th Conference on Information Visualization (IV 2008), IV-VDM Symposium on Visualization and Data Mining, IEEE Computer Society, pp. 287- 295. 